\title{
Assessment of the Susceptibility of Boar Semen to Oxidative Stress
}

\author{
Cyril Mpho Pilane ${ }^{1 *}$, Malebogo Audrey Bopape1,2, Mohleko Helen Mapeka1, \\ Thivhilaheli Richard Netshirovha1,3 \\ ${ }^{1}$ Agricultural Research Council, Animal Production Institute, Germplasm Conservation \& Reproductive \\ Biotechnologies, Pretoria, South Africa \\ ${ }^{2}$ Department of Animal Science, Faculty of Science, Tshwane University of Technology, Pretoria, South Africa \\ ${ }^{3}$ Faculty of Health and Environmental Science School of Agriculture and Environmental Science, Central \\ University of Technology, Bloemfontein, South Africa \\ Email: *cyril@arc.agric.za
}

Received 6 February 2016; accepted 18 April 2016; published 21 April 2016

Copyright (C) 2016 by authors and Scientific Research Publishing Inc.

This work is licensed under the Creative Commons Attribution International License (CC BY). http://creativecommons.org/licenses/by/4.0/

c) (i) Open Access

\section{Abstract}

The present study was conducted to assess boar sperm susceptibility to oxidative stress generated by hydrogen peroxide $\left(\mathrm{H}_{2} \mathrm{O}_{2}\right)$. Semen was collected in replicates from three experimental large white boars using the gloved-hand technique. Semen ejaculates from three boars were treated with different concentrations of $\mathrm{H}_{2} \mathrm{O}_{2}$ for three hours. SYBR-14 and Propidium Iodide (PI) Live/ Dead assay kit was used to determine cell viability, and Yo-pro-1 and PI apoptosis kit was used to determine cell death, namely, apoptosis. Boar sperm motility obtained using computer aided sperm analysis (CASA) was between $90 \%$ and $100 \%$ with more than $98 \%$ viability with $0 \%$ apoptotic cells. In $\mathrm{H}_{2} \mathrm{O}_{2}$ treated boar sperm cells, rapid (RAP) and progressive motility (PM) increased. Also, $\mathrm{H}_{2} \mathrm{O}_{2}$ treatment induced a high positive correlation with apoptosis but high negative correlation with viability. Hydrogen peroxide decreased boar semen total motility (TM) by $10 \%$. In addition, most of the boar sperm cells became apoptotic and lost $55 \%$ of viability under oxidative stress induced by $\mathrm{H}_{2} \mathrm{O}_{2}$. This study illustrated that boar semen was more susceptible to oxidative stress induced by $\mathrm{H}_{2} \mathrm{O}_{2}$.

\section{Keywords}

Oxidative Stress, Motility, Apoptosis, Viability, Semen

\footnotetext{
${ }^{*}$ Corresponding author.
}

How to cite this paper: Pilane, C.M., Bopape, M.A., Mapeka, M.H. and Netshirovha, T.R. (2016) Assessment of the Susceptibility of Boar Semen to Oxidative Stress. Open Journal of Animal Sciences, 6, 123-130. 


\section{Introduction}

Semen quality is an important factor in the livestock industry for successful quality breeding and cryopreservation [1]. Procedures required during breeding and cryopreservation, include semen collection, processing, freezing and thawing [2]. Following semen collection, there is an increase in the production of free radicals generally known as reactive oxygen species (ROS) which induces sperm cell death accompanied by decreases in sperm cell motility and viability [3]. The produced ROS includes hydrogen peroxide $\left(\mathrm{H}_{2} \mathrm{O}_{2}\right)$, hydroxyl $\left(\mathrm{OH}^{-}\right)$and superoxide anion $\left(\mathrm{O}_{2}^{-}\right)$, which are capable of dismutating either spontaneously or enzymatically to $\mathrm{H}_{2} \mathrm{O}_{2}$ [4] . These ROS are highly reactive and can interact with nearby molecules, inducing oxidative stress damage to cellular organelles and molecules, leading to sperm infertility [5]-[7]. Normally, physiological levels of ROS are required for normal sperm function such as hyperactivation, capacitation, and acrosome reaction [8] [9]. Antioxidants, like Dithiothreitol (DTT), have previously been used to improve semen motility [10]. However, oxidative stress can occur in spermatozoa when global levels of ROS (both extra- and intra-cellular) exceed the available total antioxidant capacity of that spermatozoon. Motile sperm cells have been shown to be activated by excessive ROS formation and undergo apoptosis-like changes [11]-[14].

Reactive oxygen species with relatively long half-life inhibits human sperm motility at high concentrations [15]. Also, Pilane and La Belle [16] have previously shown that apoptosis induced by oxidative stress, due to ROS, mediates the release of membrane fatty acid, in a programmed signalling pathway (apoptosis). Since apoptosis and cell viability are largely characterised by sperm permeability, the fertilizing potential of a sperm under oxidative stress can be determined based on their membrane permeability. Certain dyes, such as the green fluorescent Yo-Pro-1 dye, a green fluorescent dye, can enter apoptotic cells due to their selective permeability, whereas propidium iodide (PI), a red fluorescent dye, cannot enter the live or apoptotic cell but requires a cell with a damaged membrane to enter [17]. Similarly, SYBR-14 is a DNA binding fluorescent dye which is cell membrane permeable. It is commonly used for analysing the viability and fertilizing potential of a sperm [18].

Currently, computerized analyzing systems, like computer aided sperm class analyzer (CASA), provide the best way for semen motility assessment of collected semen [19]. It is a sensitive tool in reproductive research, and has been extensively used in the sperm motility analysis of various species [20] [21]. Parameters, such as the TM, PM, RAP, curvilinear velocity (VCL), straight line velocity (VSL), average path velocity (VAP), linearity (LIN), straightness (STR) and wobble (WOB), give valuable information on the motility and velocity parameters of semen using CASA. To our knowledge, a demonstration of the susceptibility of Large White boar semen to oxidative stress as well as their sperm motility, viability and apoptosis assessment has never been reported. This is important for cryopreservation purposes since the inclusion of antioxidants in preservation media is a necessity. Therefore, the present study was conducted to assess the vulnerability of boar semen to oxidative stress.

\section{Materials and Methods}

The study was conducted at the Pig Research Unit of Agricultural Research Council, Germplasm Conservation \& Reproductive Biotechnologies Unit, Irene, South Africa. The Agricultural Research Council-Irene campus is located at $25^{\circ} 55^{\prime}$ South; $28^{\circ} 12^{\prime}$ East. The institute is located in the Highveld region of South Africa and situated at an altitude of 1525 meters above sea level. Three exotic Large White boars were used for this study at the ages of 2 to 3 years of age. The Large White boars were in good health condition throughout the duration of the study.This study was carried out in strict accordance with the recommendations in the Guide for the Care and Use of Animals under the guidelines of the Agricultural Research Council, Animal Production Institute Animal Ethics Committee (APIEC/13/002). Boars were fed grower diet and water was given ad libitum throughout the duration of the study.

\subsection{Boar Semen Collection and Processing}

Semen samples were collected in spring (September-November) from the experimental boars. From each of the three superior boars used in this study, six ejaculates were collected separately using the gloved-hand technique in a $300 \mathrm{~mL}$ glass beaker. The filtered semen fraction was sealed with a gauze filter inside a pre-warmed $\left(39^{\circ} \mathrm{C}\right)$ insulated thermos flask. After collection, the semen samples were placed into the thermo-flask at $39^{\circ} \mathrm{C}$ and transported to the laboratory where semen evaluations were performed within $1 \mathrm{~h}$ of collection. For all the replicates, semen volume was measured by using the graduated falcon tube, $\mathrm{pH}$ was measured using the litmus pa- 
per, the sperm concentration was measured using the spectrophotometer (Jenway 6310 spectrophotometer, Bibby Scientific, England), the sperm motility rates were assessed using the CASA system (Sperm Class Analyzer $^{\circledR}$ [SCA] 5.0, Microptic, Barcelona, Spain), sperm viability and apoptosis were evaluated using the SYBR/PI live/dead kit (Invitrogen, Molecular probes, USA) and Yo-Pro-1/PI apoptosis kit (Invitrogen, Molecular probes, USA) respectively under a fluorescent microscope (Olympus model, BX-51).

\subsection{Treatments}

For semen treatment, $\mathrm{H}_{2} \mathrm{O}_{2}$ stock solution was prepared in pre-warmed $\mathrm{BO}$-Wash and kept at $4^{\circ} \mathrm{C}$ until use. During the experiment, semen at equal concentration and volume was treated with pre-warmed $\mathrm{H}_{2} \mathrm{O}_{2}$ stock to make $0,5 \mu \mathrm{M}, 50 \mu \mathrm{M}$ and $200 \mu \mathrm{M}$ concentrations. The treated cells were then incubated at $37^{\circ} \mathrm{C}$ for three hours in a humidified $5 \% \mathrm{CO}_{2}$ and $95 \%$ atmospheric air incubator (Sanyo, Japan). After three hours the cells were evaluated for total motility, progressive motility, rapid motility, semen velocities, viability and apoptosis.

\subsection{Determination of Sperm Concentration}

The sperm concentration was determined with the aid of spectrophotometer using the following formula $(76) \times$ [21.39 $\times$ (Absorbance) - 1.09] for boar sperm concentration determinations. Briefly, $3 \mathrm{~mL}$ of a $2.9 \%$ sodium citrate was placed in a cuvette and placed in a spectrophotometer set at $650 \mathrm{~nm}$ wavelength before calibration. After calibration, the absorbance of the diluted semen sample was recorded and the given formula was used to determine the semen concentration.

\subsection{Sperm Motility Rate}

Briefly, $10 \mu \mathrm{l}$ of raw semen was placed into $500 \mu \mathrm{L}$ of BO-Wash medium in $15 \mathrm{~mL}$ tube (Falcon ${ }^{\circledR} 352099$, USA). The tube was then kept in $\mathrm{CO}_{2}$ incubator (Sanyo, Japan) adjusted to $39^{\circ} \mathrm{C}$. Five micro litres of semen was placed on the warm glass slide $(\sim 76 \times 26 \times 1 \mathrm{~mm}$, Germany) and placed with a warmed cover slip $(22 \times 22 \mathrm{~mm}$, Germany) over the microscope-warm plate (Omron) adjusted at $39^{\circ} \mathrm{C}$. The sperm motility rates (Table 1) were evaluated by computer assisted sperm analysis system (Sperm Class Analyzer ${ }^{\circledR}$ [SCA] 5.0, Microptic, Barcelona, Spain) at the $10 \times$ magnification (Nikon, China).

\subsection{Viability Assay}

For cell viability, SYBR-14 and PI Live/Dead kit was used and the cells were treated according to the manufacturer's recommendation (Invitrogen, Molecular probes, USA). Briefly, $50 \mu \mathrm{L}$ of semen was diluted with prewarmed BO-Wash to $1 \mathrm{~mL}$ and $5 \mu \mathrm{L}$ of a 50 times diluted SYBR-14 was added to the cells followed by incubation at $37^{\circ} \mathrm{C}$ for 10 minutes. After 10 minutes, $5 \mu \mathrm{L}$ of propidium iodide was added to the cells followed by incubation for an additional 10 minutes. After 10 minutes, $5 \mu \mathrm{L}$ of cells were immediately placed on pre-warmed glass slide and observed under a fluorescent microscope (Olympus, model BX51). For this analysis, viable

Table 1 . The sperm motility and velocity parameters.

\begin{tabular}{|c|c|c|}
\hline Parameter & Definition & Unit \\
\hline Total Motility (TM) & Percent of sperm showing any movement & $\%$ \\
\hline Progressive Motility (PM) & Percent of sperm moving rapidly and in a straight path & $\%$ \\
\hline Rapid Motility (RAP) & Percent of sperm traveling at a speed of $25 \mu \mathrm{m} / \mathrm{sec}$ or faster & $\%$ \\
\hline Curvilinear Velocity (VCL) & Time-average velocity of sperm head along its actual path & $\mu \mathrm{m} / \mathrm{s}$ \\
\hline Straight Line Velocity (VSL) & Time-average velocity of sperm head projected along straight line & $\mu \mathrm{m} / \mathrm{s}$ \\
\hline Average Path Velocity (VAP) & Time-average velocity of sperm head projected along its spatial trajectory & $\mu \mathrm{m} / \mathrm{s}$ \\
\hline Linearity (LIN) & Ratio of projected length to total length of curvilinear trajectory; LIN = VSL/VCL & $\%$ \\
\hline Straightness (STR) & $\begin{array}{l}\text { Ratio of projected length to average velocity of sperm head along a spatial trajectory, STR = } \\
\text { VSL/VAP }\end{array}$ & $\%$ \\
\hline Wobble (WOB) & $\begin{array}{l}\text { Expression of the degree of oscillation of the curvilinear path about its spatial average path; } \\
\text { WOB }=\text { VAP/VCL }\end{array}$ & $\%$ \\
\hline
\end{tabular}


cells appeared green in colour due to SYBR while non-viable cells appear red due to propidium iodide. The percent cell viability was determined by counting the number of green cells out of a hundred cells in a field. The data was represented in a table as percent viability versus $\mathrm{H}_{2} \mathrm{O}_{2}$ concentrations.

\subsection{Apoptosis Assay}

To determine cell apoptosis, cells were treated with the Yo-Pro-1/PI staining kit solutions according to the manufacturer's recommendations (Invitrogen, Molecular probes, USA). In brief, cells were treated with $5 \mu \mathrm{L}$ of Yo-Pro-1 and PI at the same time and incubated for 10 minutes. After incubation, $5 \mu \mathrm{L}$ of the stained cells was placed on a pre-warmed slide and viewed under a fluorescent microscope (Olympus, model BX51). Four populations of cells were obtained, the light green or clear (live cells), the dark green (apoptotic cells), and red (dead/ necrotic cells) and the red and green cells (dead cells). The percent cell apoptotic cells were determined by counting the number of dark green cells out of a hundred cells in a field. The data was represented in a table as percent apoptosis versus $\mathrm{H}_{2} \mathrm{O}_{2}$ concentrations.

\subsection{Data Analysis}

The apoptosis and viability data was expressed as a percentage of total cells observed in a field, out of 300 sperm cells observed. Pearson's correlation coefficients were calculated to test the relationship between the motility rates parameters (Table 1), namely, TM, PM, RAP, VCL, VSL, VAP, LIN, STR, WOB, apoptosis and viability against the treatments. Replicate data was analyzed using the Kolmogorov-Smirnov test to determine their distribution, a multivariate analysis of variance was performed (ANOVA) and when significant differences were found, non-parametric Mann-Whitney U-test was used to compare pairs of values directly if data did not adjust to a normal distribution. All analyses were performed using SPSS version 17.0 for Windows (SPSS Inc., Chicago, IL). Significance was set at $\mathrm{P} \leq 0.05$.

\section{Results}

Our results indicates that the SYBR-14/PI staining of sperm cells for viability can clearly distinguish between viable (green) and non-viable/dead cells (red) (Figure 1). Similarly, the Yo-Pro-1/PI apoptosis assay can also clearly distinguish between, live (light green/clear) and apoptotic cells (dark green) plus dead (red) (Figure 2). The raw semen obtained from boars showed $97 \pm 2.5$ viability and no apoptotic sperm (Table 2). The boar semen volume was $144 \pm 16.3 \mathrm{~mL}$ at the $\mathrm{pH}$ of $7.0 \pm 0.0$. Raw boar semen concentration was $0.987 \pm 186.21 \times 10^{9}$ cells $/ \mathrm{mL}$ and raw semen TM was $94.07 \pm 4.11$, PM $23.3 \pm 4.94$ and RAP $4.0 \pm 0.93$ (Table 2). For the semen velocity parameters, the wobble (WOB) was $63.5 \pm 0.5$ (Table 3 ).

\section{Boar sperm viability}

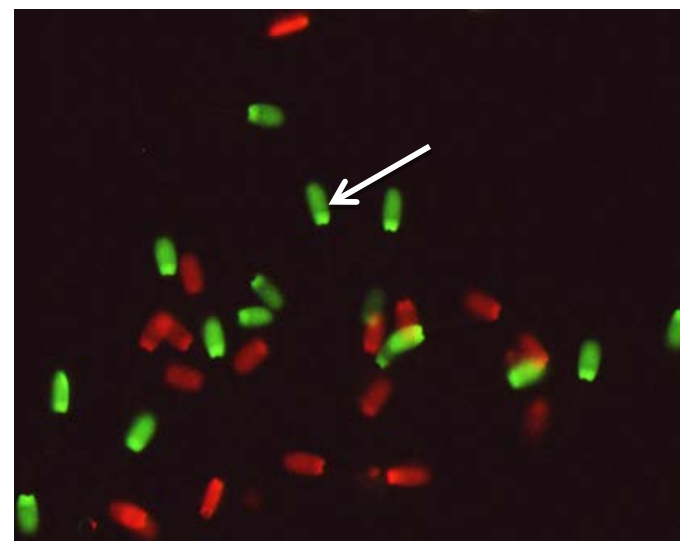

Figure 1. The images indicating the boar semen viability determined using the SYBR/PI staining method. Arrows indicate viable cells which appear green while dead cells appear red in colour. 


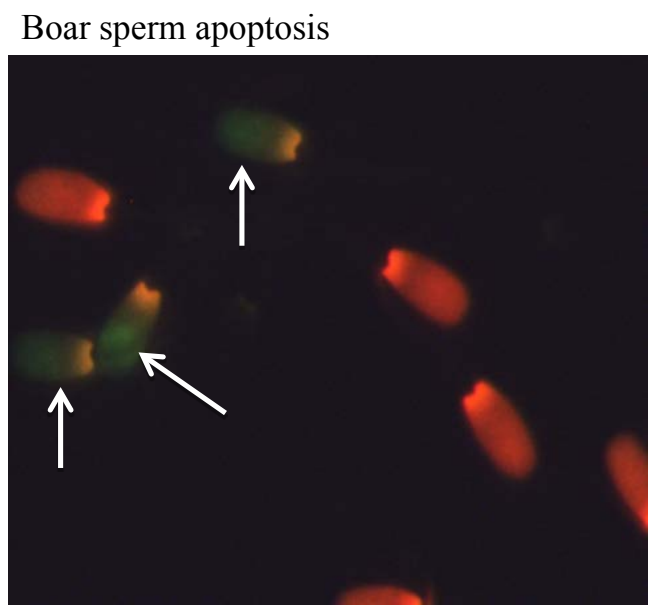

Figure 2. The images indicating the boar semen apoptosis as determined using the Yo-pro-1/PI staining method. Arrows indicate apoptotic cells (green) while dead non-apoptotic cells are red in colour.

Table 2. Boar semen viability, apoptosis and macroscopic evaluations.

\begin{tabular}{cccccc}
\hline Raw semen & $\begin{array}{c}\text { Concentration } \\
\left(1 \times 10^{9} \text { sperm cells } / \mathrm{mL}\right)\end{array}$ & $\mathrm{pH}$ & Volume $(\mathrm{mL})$ & Viability $(\%)$ & Apoptosis $(\%)$ \\
\hline Boar & $0.987 \pm 186.21^{\mathrm{a}}$ & $7.0 \pm 0.0^{\mathrm{a}}$ & $144 \pm 16.3^{\mathrm{b}}$ & $97.5 \pm 2.5^{\mathrm{a}}$ & $0.00^{\mathrm{a}}$ \\
\hline a, b Values with different subscripts with the same column differ significantly $(\mathrm{P} \leq 0.05)$. & &
\end{tabular}

Table 3. The sperm motility and velocity rates of boar raw semen.

\begin{tabular}{|c|c|c|c|c|c|c|c|c|c|}
\hline $\begin{array}{c}\text { Raw } \\
\text { semen }\end{array}$ & TM\% & PM\% & RAP\% & $\begin{array}{c}\mathrm{VCL} \\
(\mu \mathrm{m} / \mathrm{s})\end{array}$ & $\begin{array}{c}\text { VSL } \\
(\mu \mathrm{m} / \mathrm{s})\end{array}$ & $\begin{array}{c}\text { VAP } \\
(\mu \mathrm{m} / \mathrm{s})\end{array}$ & LIN\% & STR\% & WOB $\%$ \\
\hline Boar & $\begin{array}{c}94.07 \pm \\
4.11^{\mathrm{a}}\end{array}$ & $\begin{array}{c}23.3 \pm \\
4.94^{\mathrm{a}}\end{array}$ & $\begin{array}{l}4.0 \pm \\
0.93^{\mathrm{a}}\end{array}$ & $\begin{array}{c}66.2 \pm \\
3.69^{\mathrm{a}}\end{array}$ & $\begin{array}{c}28.4 \pm \\
2.52^{\mathrm{a}}\end{array}$ & $\begin{array}{c}48.27 \pm \\
2.89^{\mathrm{a}}\end{array}$ & $\begin{array}{c}58.67 \pm \\
2.81^{\mathrm{a}}\end{array}$ & $\begin{array}{c}73.3 \pm \\
7.72^{\mathrm{a}}\end{array}$ & $\begin{array}{c}77.95 \pm \\
4.95^{\mathrm{a}}\end{array}$ \\
\hline
\end{tabular}

${ }^{\mathrm{a}, \mathrm{b}}$ Values with different subscripts with the same column differ significantly $(\mathrm{P} \leq 0.05)$.

Treatment of semen from the boars with hydrogen peroxide for 3 hours, in the presence or absence of DTT, revealed that TM in boars was decreased by $5 \mu \mathrm{M}, 50 \mu \mathrm{M}$ and $200 \mu \mathrm{M}$ hydrogen peroxide from $41.7 \pm 12.6$ to $29.1 \pm 5.2,36.4 \pm 13.7$ and $31.5 \pm 10.1$, respectively and the presence of DTT had no effect. For the PM of boar semen, hydrogen peroxide had no effect but DTT improved PM in $200 \mu \mathrm{M}$ hydrogen peroxide treated semen from $2.63 \pm 1.09$ to $22.7 \pm 3.12$. Hydrogen peroxide also increased the RAP of boar semen in a concentration dependent manner and DTT had no effect. Also, this hydrogen peroxide concentration significantly decreased LIN, (from $50.5 \pm 7.89$ to $36.3 \pm 8.07$ ) and STR (from $67.23 \pm 4.57$ to $50.0 \pm 7.89$ ) but had no significant effect on other semen velocity parameters (Table 4). In the presence of DTT, VSL $(53.47 \pm 5.16)$ and VAP (60.07 \pm 3.91) were increased as compared to the untreated control ( $24.27 \pm 12.09$ and $36.00 \pm 16.68$ respectively (Table 4).

Apoptosis analysis of hydrogen peroxide treated boar semen revealed an increase in apoptosis in the presence or absence of DTT. This data is illustrated by Pearson's correlation coefficient analysis (Table 5). A moderate correlation is observed with rapid motility in hydrogen peroxide treated boar semen. Interestingly, the presence of DTT improved the correlation of hydrogen peroxide treatment with VSL (from $r=-0.352$ to $r=0.997$ ), VAP (from $r=0.623$ to $r=0.978$ ), LIN (from $r=0.256$ to $r=0.975$ ), STR (from $r=-0.839$ to $r=0.733$ ) while WOB (from $r=-0.934$ to $r=-0.829)$ did not change. Also, high positive correlation $(r=0.919)$ is observed with hydrogen peroxide treatment and apoptosis and high negative correlation $(r=-0.9996)$ was observed with boar semen viability. In the presence of DTT, the boar semen apoptosis correlation with hydrogen peroxide remain high while the viability correlation $(\mathrm{r}=-0.0958)$ is lost. This means that in the presence of DTT, the boar semen progressive motility is restored but the apoptosis remain high while the viability is improved (Table 5). 
Table 4. The sperm motility and velocity rates of treated boar semen.

\begin{tabular}{|c|c|c|c|c|c|c|c|c|c|}
\hline Boar Semen & $\% \mathrm{TM}$ & $\% \mathrm{PM}$ & $\%$ RAP & $\begin{array}{l}\mathrm{VCL} \\
(\mu \mathrm{m} / \mathrm{s})\end{array}$ & $\begin{array}{l}\mathrm{VSL} \\
(\mu \mathrm{m} / \mathrm{s})\end{array}$ & $\begin{array}{l}\text { VAP } \\
(\mu \mathrm{m} / \mathrm{s})\end{array}$ & $\% \mathrm{LIN}$ & $\%$ STR & $\%$ WOB \\
\hline Control & $\begin{array}{r}41.7 \pm \\
12.6^{\mathrm{a}}\end{array}$ & $\begin{array}{c}3.3 \pm \\
1.4^{\mathrm{a}}\end{array}$ & $\begin{array}{l}0.7 \pm \\
0.78^{\mathrm{a}}\end{array}$ & $\begin{array}{c}46.03 \pm \\
15^{\mathrm{a}}\end{array}$ & $\begin{array}{c}24.27 \pm \\
12^{\mathrm{a}}\end{array}$ & $\begin{array}{c}36.00 \pm \\
16.6^{\mathrm{a}}\end{array}$ & $\begin{array}{c}50.5 \pm \\
7.89^{\mathrm{a}}\end{array}$ & $\begin{array}{c}67.23 \pm \\
4.57^{\mathrm{a}}\end{array}$ & $\begin{array}{l}79.4 \pm \\
4.94^{\mathrm{a}}\end{array}$ \\
\hline $5 \mu \mathrm{M} \mathrm{H}_{2} \mathrm{O}_{2}$ & $\begin{array}{c}29.1 \pm \\
5.2^{\mathrm{a}}\end{array}$ & $\begin{array}{l}1.0 \pm \\
0.4^{\mathrm{a}}\end{array}$ & $\begin{array}{l}0.2 \pm \\
0.21^{\mathrm{a}}\end{array}$ & $\begin{array}{c}59.1 \pm \\
2.01^{\mathrm{a}}\end{array}$ & $\begin{array}{c}27.67 \pm \\
6.9^{\mathrm{a}}\end{array}$ & $\begin{array}{c}47.83 \pm \\
3.86^{\mathrm{a}}\end{array}$ & $\begin{array}{c}47.0 \pm \\
12.2^{\mathrm{a}}\end{array}$ & $\begin{array}{c}57.43 \pm \\
11.3^{\mathrm{a}}\end{array}$ & $\begin{array}{c}80.96 \pm \\
5.63^{\mathrm{a}}\end{array}$ \\
\hline $50 \mu \mathrm{M} \mathrm{H}_{2} \mathrm{O}_{2}$ & $\begin{array}{c}36.4 \pm \\
13.7^{\mathrm{a}}\end{array}$ & $\begin{array}{l}2.3 \pm \\
0.4^{\mathrm{a}}\end{array}$ & $\begin{array}{c}0.83 \pm \\
0.40^{\mathrm{a}}\end{array}$ & $\begin{array}{c}61.57 \pm \\
4.7^{\mathrm{a}}\end{array}$ & $\begin{array}{r}26.7 \pm \\
7.58^{\mathrm{a}}\end{array}$ & $\begin{array}{c}46.63 \pm \\
11.6^{\mathrm{a}}\end{array}$ & $\begin{array}{c}43.50 \pm \\
12.9^{\mathrm{a}}\end{array}$ & $\begin{array}{c}57.13 \pm \\
10.7^{\mathrm{a}}\end{array}$ & $\begin{array}{c}75.2 \pm \\
14.9^{\mathrm{a}}\end{array}$ \\
\hline $200 \mu \mathrm{M} \mathrm{H}_{2} \mathrm{O}_{2}$ & $\begin{array}{c}31.5 \pm \\
10.1^{\mathrm{a}}\end{array}$ & $\begin{array}{c}2.6 \pm \\
1.0^{\mathrm{a}}\end{array}$ & $\begin{array}{l}1.067 \pm \\
0.6^{\mathrm{a}}\end{array}$ & $\begin{array}{c}66.7 \pm \\
5.76^{\mathrm{a}}\end{array}$ & $\begin{array}{c}24.83 \pm \\
7.1^{\mathrm{a}}\end{array}$ & $\begin{array}{l}49.3 \pm \\
12.81^{\mathrm{a}}\end{array}$ & $\begin{array}{c}36.60 \pm \\
8.07^{\mathrm{a}}\end{array}$ & $\begin{array}{c}50.0 \pm \\
1.74^{\mathrm{a}}\end{array}$ & $\begin{array}{l}72.7 \pm \\
13.89^{\mathrm{a}}\end{array}$ \\
\hline DTT & $\begin{array}{r}45.4 \pm \\
16.4^{\mathrm{a}}\end{array}$ & $\begin{array}{l}7.2 \pm \\
4.8^{\mathrm{b}}\end{array}$ & $\begin{array}{c}0.93 \pm \\
0.4^{\mathrm{a}}\end{array}$ & $\begin{array}{c}61.3 \pm \\
16.9^{\mathrm{a}}\end{array}$ & $\begin{array}{l}21.3 \pm \\
7.26^{\mathrm{a}}\end{array}$ & $\begin{array}{c}44.67 \pm \\
13.7^{\mathrm{a}}\end{array}$ & $\begin{array}{l}35.1 \pm \\
6.63^{\mathrm{a}}\end{array}$ & $\begin{array}{l}47.3 \pm \\
1.51^{\mathrm{a}}\end{array}$ & $\begin{array}{l}75.0 \pm \\
11.57^{\mathrm{a}}\end{array}$ \\
\hline $\begin{array}{c}5 \mu \mathrm{M} \mathrm{H}_{2} \mathrm{O}_{2}+ \\
\text { DTT }\end{array}$ & $\begin{array}{c}29.1 \pm \\
17^{\mathrm{a}}\end{array}$ & $\begin{array}{c}2.5 \pm \\
1.3^{\mathrm{a}}\end{array}$ & $\begin{array}{l}0.3 \pm \\
0.22^{\mathrm{a}}\end{array}$ & $\begin{array}{c}66.6 \pm \\
4.18^{\mathrm{a}}\end{array}$ & $\begin{array}{c}24.4 \pm \\
5.53^{\mathrm{a}}\end{array}$ & $\begin{array}{l}47.6 \pm \\
10.30^{\mathrm{a}}\end{array}$ & $\begin{array}{l}36.4 \pm \\
7.32^{\mathrm{a}}\end{array}$ & $\begin{array}{c}51.3 \pm \\
5.50^{\mathrm{a}}\end{array}$ & $\begin{array}{c}70.9 \pm \\
11.5^{\mathrm{a}}\end{array}$ \\
\hline $\begin{array}{c}50 \mu \mathrm{M} \mathrm{H}_{2} \mathrm{O}_{2} \\
\text { DTT }\end{array}$ & $\begin{array}{c}36.4 \pm \\
13.7^{\mathrm{a}}\end{array}$ & $\begin{array}{l}3.6 \pm \\
3.2^{\mathrm{a}}\end{array}$ & $\begin{array}{c}1.63 \pm \\
1.33^{\mathrm{a}}\end{array}$ & $\begin{array}{r}70.2 \pm \\
6.24^{\mathrm{a}}\end{array}$ & $\begin{array}{l}23.5 \pm \\
8.71^{\mathrm{a}}\end{array}$ & $\begin{array}{c}51.07 \pm \\
11.6^{\mathrm{a}}\end{array}$ & $\begin{array}{l}33.1 \pm \\
11.98^{\mathrm{a}}\end{array}$ & $\begin{array}{c}44.53 \pm \\
11.1^{\mathrm{a}}\end{array}$ & $\begin{array}{l}72.1 \pm \\
11.63^{\mathrm{a}}\end{array}$ \\
\hline $\begin{array}{c}200 \mu \mathrm{M} \mathrm{H}_{2} \mathrm{O}_{2} \\
\text { DTT }\end{array}$ & $\begin{array}{l}37.4 \pm \\
24.9^{\mathrm{a}}\end{array}$ & $\begin{array}{c}22.7 \pm \\
3.1^{\mathrm{c}}\end{array}$ & $\begin{array}{c}0.63 \pm \\
0.09^{\mathrm{a}}\end{array}$ & $\begin{array}{c}35.5 \pm \\
5.16^{\mathrm{a}}\end{array}$ & $\begin{array}{l}53.4 \pm \\
5.0^{\mathrm{b}}\end{array}$ & $\begin{array}{c}60.07 \pm \\
3.91^{\mathrm{b}}\end{array}$ & $\begin{array}{c}53.47 \pm \\
5.09^{\mathrm{a}}\end{array}$ & $\begin{array}{c}64.17 \pm \\
3.51^{\mathrm{a}}\end{array}$ & $\begin{array}{c}67.55 \pm \\
4.10^{\mathrm{a}}\end{array}$ \\
\hline
\end{tabular}

${ }^{a, b}, \mathrm{c}$ Values with different subscripts with the same column differ significantly $(\mathrm{P} \leq 0.05)$.

Table 5. Correlations of the boar semen motility rates and treatments.

\begin{tabular}{ccc}
\hline & - DTT & +DTT \\
\hline Total Motility & Boar Semen & Boar Semen \\
\hline Rapid Motility & $-0.368^{\mathrm{a}}$ & $-0.00844^{\mathrm{b}}$ \\
Progressive Motility & $0.7988^{\mathrm{a}}$ & $-0.532^{\mathrm{b}}$ \\
VCL & $0.0753^{\mathrm{a}}$ & $0.9268^{\mathrm{b}}$ \\
VSL & $-0.743^{\mathrm{a}}$ & $0.252^{\mathrm{b}}$ \\
VAP & $-0.352^{\mathrm{a}}$ & $0.997^{\mathrm{b}}$ \\
LIN & $0.623^{\mathrm{a}}$ & $0.978^{\mathrm{a}}$ \\
STR & $0.256^{\mathrm{a}}$ & $0.975^{\mathrm{b}}$ \\
WOB & $-0.839^{\mathrm{a}}$ & $0.733^{\mathrm{b}}$ \\
Apoptosis & $-0.934^{\mathrm{a}}$ & $-0.849^{\mathrm{a}}$ \\
Viability & $0.919^{\mathrm{a}}$ & $0.9841^{\mathrm{a}}$ \\
\hline
\end{tabular}

${ }^{a, b}$ Values with different subscripts with the same row differ significantly $(\mathrm{P} \leq 0.05)$.

\section{Discussions}

This study indicates that hydrogen peroxide induces oxidative damage to semen which is accompanied by changes in the semen velocity parameters, semen motility parameters and semen viability, and these are also appears to be species dependent. In boars hydrogen peroxide had variable effects on TM in the presence or absence or DTT. In boars, hydrogen peroxide decreased TM in the presence or absence of DTT. In a similar study, Griveau et al. [22] demonstrated that $50 \mu \mathrm{M}$ hydrogen peroxide accelerated the hyperactivation and acrosome reaction of semen after incubation for $3 \mathrm{~h}$. In fact, at the highest hydrogen peroxide concentration used in this study $(200 \mu \mathrm{M})$, PM decreased by about $20 \%$ in boars. Amazingly, DTT restored boar semen PM to the raw semen PM value. Also, RAP was decreased at $200 \mu \mathrm{M}$ hydrogen peroxide and decreased even further in the presence of DTT. These observations indicate that boar semen is more susceptible to ROS which affect the sperm motility parameters. This is in agreement with [23] who concluded that, the deleterious effects of ROS on the semen motility parameters, depends on the species being investigated. 
Also, $200 \mu \mathrm{M}$ hydrogen peroxide decreased VAP, LIN and STR but had no effect on VCL. The antioxidant, DTT, decreased VCL and WOB while LIN and STR which restored to raw semen values while VAP and VSL were improved. In addition, treatment with $200 \mu \mathrm{M}$ hydrogen peroxide, DTT had a decreasing effect on VCL. The decrease in semen VCL is due to a reduction in both the angle of lateral head displacement (ALH) and the beat cross frequency (BCF). A decrease in ALH means the sperm head is moving less from side to side while a decrease in BCF means these actions occur slower. Ironically, VCL in boars semen treated with $50 \mu \mathrm{M}$ hydrogen peroxide is improved by DTT, indicating that ROS levels must be lower in boar semen for antioxidants like DTT to take effect. Aitken et al. [24] have shown that $50 \mu \mathrm{M}$ hydrogen peroxide have stimulatory effects on human spermatozoa.

\section{Conclusion}

In boars, hydrogen peroxide could not improve VAP, but the presence of DTT enhanced VAP by only $10 \%$. Hydrogen peroxide decreased LIN, but LIN was restored to raw semen values by DTT. Also, STR and WOB were decreased by hydrogen peroxide and further decreased by the presence of DTT compared to raw semen values. This indicates that ROS can compromise boar sperm velocity parameters which cannot be rescued by an antioxidant, like DTT. Together, this datum demonstrates that the use of antioxidants in any boar semen processing is essential during cryopreservation.

\section{Acknowledgements}

The authors wish to acknowledge Nedambale TL for intellectual support, Agricultural Research Council (ARC) and National Research Foundation (NRF) for providing necessary facilities and financial support.

\section{References}

[1] Barth, A.D. and Waldner, C.L. (2000) Factors Affecting Breeding Soundness Classification of Beef Bulls Examined at the Western College of Veterinary Medicine. The Canadian Veterinary Journal, 43, 274-284.

[2] Bucak, M.N., Tuncer, P.B., Sariozkan, S. and Ulutas, P.A. (2009) Comparison of the Effects of Glutamine and an Amino Acid Solution on Post-Thawed Ram Sperm Parameters, Lipid Peroxidation and Anti-Oxidant Activities. Small Ruminant Research, 81, 13-17. http://dx.doi.org/10.1016/j.smallrumres.2008.10.003

[3] Thomson, L.K., Fleming, S.D., Aitken, R.J., De Luliis, G.N., Zieschang, J.A. and Clark, A.M. (2009) Cryopreservation-Induced Human Sperm DNA Damage Is Predominantly Mediated by Oxidative Stress Rather than Apoptosis. Human Reproduction, 24, 2061-2070. http://dx.doi.org/10.1093/humrep/dep214

[4] Alvarez, J.G., Touchstone, J.C., Blasco, L. and Storey, B.T. (1987) Spontaneous Lipid Peroxidation and Production of Hydrogen Peroxide and Superoxide in Human Spermatozoa. Superoxide Dismutase as Major Enzyme Protectant against Oxygen Toxicity. Journal of Andrology, 8, 338-348. http://dx.doi.org/10.1002/j.1939-4640.1987.tb00973.x

[5] Guèrin, P., Mouatassim, S. and Mènèzo, Y. (2001) Oxidative Stress and Protection against Reactive Oxygen Species in the Pre-Implantation Embryo and Its Surroundings. Human Reproduction Update, 7, 175-189. http://dx.doi.org/10.1093/humupd/7.2.175

[6] De Lamirande, E. and Gagnon, C. (1995) Impact of Reactive Oxygen Species on Spermatozoa: A Balancing Act between Beneficial and Detrimental Effects. Human Reproduction, 10, 15-21. http://dx.doi.org/10.1093/humrep/10.suppl 1.15

[7] Agarwal, A., Gupta, S. and Sharma, R.K. (2005) Role of Oxidative Stress in Female Reproduction. Reproductive Biology \& Endocrinology, 3, 28. http://dx.doi.org/10.1186/1477-7827-3-28

[8] Goncalves, F., Barretto, L.S.S., Arruda, R.P., Perri, S.H.V. and Mingoti, G.H. (2001) Effect of Antioxidants during Bovine in Vitro Fertilization Procedures on Spermatozoa and Embryo Development. Reproduction in Domestic Animals, 45, 129-135. http://dx.doi.org/10.1111/j.1439-0531.2008.01272.x

[9] Desai, N., Sharma, R., Maker, K., Sabnegh, E. and Agarwal, A. (2009) Physiological and Pathological Levels of Reactive Oxygen Species in Neat Semen of Infertile Men. Fertility \& Sterility, 92, 1626-1631. http://dx.doi.org/10.1016/j.fertnstert.2008.08.109

[10] Lindemann, C.B., O’Brien, J.A. and Giblin, F.J. (1998) An Investigation of the Effectiveness of Certain Antioxidants in Preserving the Motility of Reactivated Bull Sperm Models. Biology of Reproduction, 38, 114-120. http://dx.doi.org/10.1095/biolreprod38.1.114

[11] De Lamirande, E. and O'Flaherty, C. (2007) Sperm Activation: Role of Reactive Oxygen Species and Kinases. Bio- 
chimiaet Biophysica Acta, 1784, 106-115. http://dx.doi.org/10.1016/j.bbapap.2007.08.024

[12] Levy, R. and Seifer-Aknin, I. (2001) Apoptosis during Spermatogenesis and in Ejaculated Spermatozoa: Importance for Fertilization. Annales de Biology Clinique, 59, 531-545.

[13] Lysiak, J.J., Zheng, S., Woodson, R. and Turner, T.T. (2007) Caspase-9-Dependent Pathway to Murine Germ Cell Apoptosis: Mediation by Oxidative Stress, BAX, and Caspase 2. Cell Tissue Research, 328, 411-419. http://dx.doi.org/10.1007/s00441-006-0341-y

[14] Stevanato, J., Bertolla, R.P., Barradas, V., Spaine, D.M., Cedenho, A.P. and Ortiz, V. (2008) Semen Processing by Density Gradient Centrifugation Does Not Improve Sperm Apoptotic Deoxyribonucleic Acid Fragmentation Rates. Fertility \& Sterility, 90, 889-890. http://dx.doi.org/10.1016/j.fertnstert.2007.01.059

[15] Zini, A., De Lamirande, E. and Gagnon, C. (1995) Low Levels of Nitric Oxide Promote Human Sperm Capacitation in Vitro. Journal of Andrology, 16, 424-431.

[16] Pilane, C.M. and La Belle, E.F. (2004) No Induced Apoptosis of Vascular Smooth Muscle Cells Accompanied by Ceramide Increase. Journal of Cellular Physiology, 199, 310-315. http://dx.doi.org/10.1002/jcp.10464

[17] Krishan, A. (1987) Effect of Drug Efflux Blockers on Vital Staining of Cellular DNA with Hoechst 33342. Cytometry, 8, 642-645. http://dx.doi.org/10.1002/cyto.990080618

[18] Garner, D.L. and Johnson, L.J. (1995) Viability Assessment of Mammalian Sperm Using SYBR-14 and Propidium Iodide. Biology Reproduction, 53, 276-284. http://dx.doi.org/10.1095/biolreprod53.2.276

[19] Holt, W.V., O’Brien, J. and Abaigar, T. (2007) Applications and Interpretation of Computer-Assisted Sperm Analyses and Sperm Sorting Methods in Assisted Breeding and Comparative Research. Reproduction Fertility \& Development, 19, 709-718. http://dx.doi.org/10.1071/RD07037

[20] Working, P.K. and Hurtt, M.E. (1987) Computerised Video Micrographic Analysis of Rat Sperm Motility. Journal of Andrology, 8, 330-337. http://dx.doi.org/10.1002/j.1939-4640.1987.tb00971.x

[21] Toth, G.P., Stober, J.A., Reads, E.J., Christ, S.A. and Smith, M.K. (1991) Correlation of Sperm Motion Parameters with Fertility in Rats Treated Subchronically with Epichlorohydrin. Journal of Andrology, 12, 54-61.

[22] Griveau, J.F., Renard, P. and Le Lannou, D. (1994) An in Vitro Promoting Role for Hydrogen Peroxide in Human Sperm Capacitation. International Journal of Andrology, 17, 300-307. http://dx.doi.org/10.1111/j.1365-2605.1994.tb01260.x

[23] De Lamirande, E., Jiang, H., Zini, A., Kodama, H. and Gagnon, C. (1997) Reactive Oxygen Species and Sperm Physiology. Reviews of Reproduction, 2, 48-54. http://dx.doi.org/10.1530/ror.0.0020048

[24] Aitken, R.J., Paterson, M., Fisher, H., Buckingham, D.W. and Van Duin, M. (1995) Redox Regulation of Tyrosine Phosphorylation in Human Spermatozoa and Its Role in the Control of Human Sperm Function. Journal of Cell Science, 180, 2017-2025. 